\title{
A New Professional Landscape: Entangled Institutional Logics in Two Swedish Welfare Professions'
}

I Johan Alvehus ${ }^{2}$

Assistant Professor, Lund University, Department of Service Management and Service Studies, Sweden

\section{Thomas Andersson}

Associate Professor, University of Skövde, School of Business, Sweden

\begin{abstract}
Previous research has made three parallel but incompatible observations on the contemporary development of welfare professions: loss of professional autonomy, hybridization, and maintained autonomy. Yet, research providing contextual understanding of the simultaneous occurrence of these three observations is lacking. The aim of this theoretical paper is to identify and explain seemingly contradictory coexisting features of modern welfare professions through a comprehensive reading of current literature on the health care and teaching professions in Sweden. The literature has demonstrated entangled institutional logics, in which simultaneous but differing effects occur, thereby developing a new professional landscape.
\end{abstract}

\section{KEYWORDS}

Institutional logics / New Public Management / Professionalism / Professions / Sweden

\section{Introduction}

rofessionalism is increasingly under threat, as such neoliberal ideologies and ideals as New Public Management (NPM) have undermined the status of professionalism and its basis of legitimacy (Scott 2008). The market has entered the scene as a control mechanism and a basis for distributing resources (Hood 1995). Control systems have expanded, scrutinizing, and valuing the work of professionals according to bureaucratic frameworks rather than professional insight. Market and bureaucracy logics, often in accord with each other, supplant the logic of professionalism (Freidson 2001).

Such observations are commonplace and often lamented among researchers who aim to capture overarching trends within professions and professionalism. A number of studies have emphasized the local and inhabited character of institutional logics, however, ascribing greater agency to professionals and organisations (e.g., Bévort \& Suddaby 2016; Everitt 2012, 2013; Hallett 2010; Hallett \& Ventresca 2006; Smets et al. 2015). Professional organizations have been described as hybrids, encompassing and reconciling conflicting institutional logics (Evetts 2011; Kirkpatrick \& Noordegraaf

\footnotetext{
${ }^{1}$ You can find this text and its DOI at https://tidsskrift.dk/njwls/index.

${ }^{2}$ Corresponding author: Johan Alvehus, Department of Service Management and Service Studies, Lund University, P.O. Box 882, SE-251 08 Helsingborg, Sweden, Phone +46 (0)709740474, johan.alvehus@ ism.lu.se.
} 
2015; Pache \& Santos 2013). Yet, as Meyer and Rowan (1977) and Weick (1976) have observed, professional organizations decouple overarching organizational structures from everyday work processes; thus, management and governance systems may have a limited impact on everyday work (Alvehus 2018).

Three parallel, incompatible views have thus emerged regarding the state of professional work: (1) loss of professional autonomy and the notion that professional institutional logic is subsumed under the logic of the market and the logic of bureaucracy; (2) increased hybridization and therefore harmony among professional, managerial, and market logics, hailing new organizational forms that balance these contradictions; and (3) the loosely coupled character of professional organizations, allowing different logics to exist side by side.

These observations are made in different studies from various contexts. Thus, we do not know whether there are different lines of development in different places, or whether these three processes co-occur. The values of comparisons between studies may be limited, as systems of governance vary across contexts; comparisons that have been undertaken also tend to focus on outcomes rather than institutional logics per se (Hood \& Dixon 2015). In this article, we hold the national context constant, and focus on the professions in the two largest welfare sectors in Sweden: health care and teaching. Professions in these two sectors are of particular interest, as these sectors have been the target for numerous NPM reforms directed to limiting professional autonomy (Molander 2017). The aim of this theoretical paper is to identify and explain seemingly contradictory coexisting features of modern welfare professions through a comprehensive reading of current literature on the health care and teaching professions in Sweden. Although subjected to similar changes, the two have different characteristics. A classic group of professionals - physicians - dominate health care, but nurses have recently become more significant players, in the face of pressures to standardize health care processes. In the Swedish school system, teachers have been subjected to several decades of de-professionalization and schools have been subjected to marketization to the point that the system is considered the most market-oriented in the world. This change is noteworthy, given Sweden's long history of substantial welfare policies and social-democratic mixed economy (Kamp 2016). In fact, privatizations in the Swedish welfare sector have been substantial, but they have 'received surprisingly little attention in the international research community' and have only been 'cursorily covered' (Svallfors \& Tyllström 2018, p. 2).

Our reading demonstrates that changes in the welfare professions appear mainly in the form of three trends, hailing the advent of a new professional landscape. First, it supports the claim of an overarching trend toward organizational professionalism (Evetts 2011), in which professional ideals become subsumed under bureaucratic logic (Siebert et al. 2018) and professionals actively seek support and legitimacy from bureaucracy (Kirkpatrick \& Noordegraaf 2015). Second, there is growing stratification within the professions and development of elite segments in the professions (Currie et al. 2009). Third, professionals are broadly successful in maintaining autonomy in everyday work, thereby partly limiting the impact of nonprofessional forms of control on work processes (Alvehus 2018). From these observations, we conclude that we must appreciate the complexity of this new professional landscape and suggest viewing it as entangled institutional logics, sustained by a seemingly paradoxical relationship between centralization and decentralization, profoundly altering power relationships within professions and between professional and bureaucratic roles.

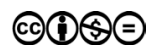


In the following, we will first address the broader topic of NPM and its presumed consequences for professional autonomy, followed by a discussion on the way conflicting institutional logics have been theorized. We then introduce the above-mentioned trends in detail, based on observations in recent literature describing developments in two welfare professions in Sweden. Building on this, our discussion further elaborates the notion of entangled institutional logics.

\section{New Public Management and professional autonomy}

Public organizations have undergone major changes in their management and organizing practices since the beginning of 1980s, which in turn has influenced professional autonomy in different ways in these organizations. NPM, whereby administrative ideas from the private sector are borrowed by the public sector, is the umbrella term characterizing these changes (Almqvist 2004). NPM comprises a cluster of ideas and elements. Because they have been attended to in different ways in different countries and different historical contexts, NPM can vary greatly in practice (Hasselbladh et al. 2008). Thus, even if NPM exists all over the Western world, in practice, it must be treated as a local phenomenon and it is dangerous to treat NPM as a single technology or ideology regarding effects on professional autonomy or other effects. As Dan and Pollitt (2015, p. 1317) argue:

Claims that either see NPM as a generic solution to most public sector ills, or those that dismiss NPM altogether, are not consonant with the available evidence. Researchers and other commentators must acknowledge that reality is more nuanced. It is very likely that NPM reforms will give rise to a host of intended and unintended consequences - some positive, others negative, some easy to control and others more difficult to manage.

NPM and other reform initiatives, drawing on efficiency-improving techniques from the private sector, have been adopted and adapted in various ways in Sweden's public sector (Karlsson 2017). The Nordic countries in general seem to practice a 'softer' version of NPM than do the UK or USA (Kamp et al. 2013). Yet, when it comes to professional autonomy, the question is whether Swedish NPM is that 'soft'. Especially health care and education has been subject to many reform attempts that explicitly or implicitly has been directed to limiting professional autonomy.

Nonetheless, NPM involves a comprehensive change in public organizations (Almqvist 2004). Trust in managers and markets has replaced trust in professionals and civil servants. Formalized accountability has replaced trust in public management, and accounting systems primarily control the exercise of public authority. The public sector is continually changing: Once governed by ideology, it is now managed by economic rationality, with a shift from budget control (based on input) to management by objectives (based on output). Yet, rather than old governing regimes being replaced, new ones have been added (Andersson \& Tengblad 2009), increasing the complexity of public-sector management and professional work. Several logics are simultaneously at play, and there may even be a paradoxical situation of more professionalism and more managerialism (Kamp 2016), which may be one explanation behind the three parallel, but incompatible views on contemporary development of professional autonomy. 


\section{Conflicting institutional logics?}

Organizations are governed and organized in conformity with societal norms and expectations. Neo-institutional theory (e.g., DiMaggio \& Powell 1983) states that isomorphism is produced through coercion, mimetic processes, and normative pressures for conformity. Organizations seek legitimacy from their environment by converging around field-specific, institutional logics: 'The socially constructed, historical patterns of material practices, assumptions, values, beliefs, and rules by which individuals produce and reproduce their material subsistence, organize time and space, and provide meaning to their social reality' (Thornton \& Ocasio 1999, p. 804). Institutional logics 'specify which issues to consider salient, which ends to pursue, which means to employ, and which standards to use to define success' (Smets et al. 2015, p. 934) and they both enable and constrain individual, socially embedded agency and action, providing resources for performing work and serving as vocabularies to make sense of and legitimize organizational processes.

Yet, differing logics are often considered incompatible. Whereas according to the professional-bureaucratic conflict model, there is inherent conflict between different logics in an ideal-type sense (Freidson 2001, Wallace 1995), this does not mean that they cannot coexist empirically. Empirical researchers have questioned the validity of understanding these abstract models as empirical instances (Reay \& Hinings 2009). There are also variations creating conflicts within the same institutional logic - through ongoing power games among various professional groups harboring diverging professional goals (Collin et al. 2015), for example. Goodrick and Reay (2011) show how professional work can be guided over time by different logic constellations, and Waldorff et al. (2013) explain that they can generate national differences within an industry. Furthermore, Smets et al. (2015) explain how logics can be conflicting yet complementary through dynamic tension. This does not mean that the value of logics as analytical tools is invalid, but that researchers have started to expand on the coexistence of different logics in organizations, rather than assuming inherent conflict and incompatibility.

Professional organizations have long been noted for using various forms of control in addition to professionalism - management by objectives (Covaleski et al. 1998; Dirsmith et al. 1997), human resource management (Swart et al. 2015), and financial control (Alvehus \& Spicer 2012), for instance. They conflict with traditional professional forms of governance and management (Greenwood et al. 1990), and new forms have emerged (Adler et al. 2008; Cooper et al. 1996; Faulconbridge \& Muzio 2008). Despite inconsistencies between logics, there has been an increasing emphasis on the hybridity of professional organizations, in which different logics are combined (Kirkpatrick \& Noordegraaf 2015). Organizations can also combine elements of these logics (Pache \& Santos 2013; Singh \& Jayanti 2013) to create a 'balance between logics' (Battilana \& Dorado 2010, p. 1420). Moreover, many types of organizations are loosely coupled systems, wherein logics can coexist (Brunsson 1989; Weick 1976). Furthermore, organizations may privilege a dominant logic, while simultaneously sustaining another by 'inverted appropriation' (Alvehus 2018).

The traditional conflict model of institutional logics has been challenged, and there are calls for more nuanced approaches (Andersson \& Liff, 2018). Many of these studies are case studies that provide little insight into the influence of institutional context on organizational fields. The interpretation and employment of NPM is highly dependent on 
national, sociohistorical, and cultural contexts, as is the notion of professionalism (Adams 2015; Hasselbladh et al. 2008). In order to facilitate comparisons between professions, this review focuses on health care and teaching in Sweden. Both sectors have implemented similar institutional changes in the form of Swedish NPM (Hasselbladh et al. 2008; Montin 1997). This review is concerned with the broader tendencies of organizational and professional adaptation to institutional logics within a singular context, with the analysis acknowledging recent developments in theories of professional organizations.

\section{Recent developments in the Swedish welfare professions}

Sweden has long been known for its use of the Nordic model within the public sector, with high taxes and trusted social institutions; '[s]ocial democratic meanings and practices are quite deeply entrenched in Swedish daily life' (Belfrage 2008, p. 290). In the mid-1990s, Sweden increasingly implemented NPM reforms, spawning debates around the need for increased professional accountability and efficiency and an increased tendency toward de-professionalization (Hasselbladh et al. 2008). These developments have been profound; privatization and NPM reforms in Sweden have been rapid, extensive, and resilient (Molander 2017; Svallfors \& Tyllström 2018).

Table I Summary of comparison between two Swedish welfare professions

\begin{tabular}{|c|c|}
\hline \multicolumn{2}{|l|}{ Trend I: Organizational professionalism } \\
\hline Examples from health care & Examples from education \\
\hline $\begin{array}{l}\text { - } \quad \text { gPM interventions in many areas simultaneously, } \\
\text { - } \quad \text { Standardization and bureacratization of professional } \\
\text { - work, driven by professionals themselves } \\
\text { - } \quad \text { Professionals engaged in bureaucratization activities } \\
\text { customeners }\end{array}$ & $\begin{array}{l}\text { - } \quad \text { Principals' lack of pedagogical knowledge } \\
\text { - } \quad \text { leads to increased fous on management } \\
\text { translating bureaucratic logic } \\
\text { - } \quad \text { Increased presence of nonteaching } \\
\text { activities in teachers' work, increased } \\
\text { intensification of nonclassroom work }\end{array}$ \\
\hline \multicolumn{2}{|l|}{ Trend 2: Increasing stratification } \\
\hline Examples from health care & Examples from education \\
\hline $\begin{array}{l}\text { - } \quad \text { Elite professionals managing formal evaluation systems } \\
\text { - Hybrid positions enable reconciliation of different log- } \\
\text { ics, individuals in such positions gain increased power } \\
\text { - Management positions destabilize traditional inter- } \\
\text { professional power relations }\end{array}$ & $\begin{array}{l}\text { - School managers' role becomes special- } \\
\text { ized on administration and expands into } \\
\text { leadership rather than pedagogy } \\
\text { - Introduction of elite professionals in } \\
\text { form of 'first teachers' }\end{array}$ \\
\hline \multicolumn{2}{|l|}{ Trend 3: Retained autonomy } \\
\hline Examples from health care & Examples from education \\
\hline $\begin{array}{l}\text { - Physicians gain a veto position in relation to bureauc- } \\
\text { tatic processes } \\
\text { - Loose coupling between management models and } \\
\text { professional practices }\end{array}$ & $\begin{array}{l}\text { - Teachers retain power to hamper } \\
\text { change initiatives } \\
\text { - Stratification decreases control over } \\
\text { teachers' everyday work } \\
\text { - Abstract frameworks require interpreta- } \\
\text { tion and therefore enable autonomy }\end{array}$ \\
\hline
\end{tabular}


In this paper, we not only partly confirm these concerns but also provide insights into responses to changes. Both sectors - health care and teaching - have undergone various reforms with the effect of increasing control and management. In this, limiting professional autonomy has been an integral part. Yet, to what extent has management been able to influence professional work processes and professional judgement, and has that influence made any impact on patients and pupils? Whereas our overview and analysis shows that although the general theme of a professional logic under threat can be discerned, developments are more nuanced and multifaceted. We have identified three broad trends in these institutional changes (see Table 1), which taken together constitute a paradoxical image comprising conflicting developments. Below, we present each trend and give examples.

\section{Trend I: Increasing organizational professionalism}

NPM has become a fundamental part of the Swedish health care system (Hasselbladh et al. 2008). The transformation has extended beyond basic ambitions of NPM in terms of monetization, cost control, and market mechanisms and has come to include ethics, responsibilities, legitimacy and politics, ingraining control in professional practice. Boundaries between bureaucratic logics of control and the professional logic of everyday work become blurred when professionals are drawn into complex control and management activities, where professional performance is scrutinized.

Whereas managers cannot directly influence physicians, physicians are seized by bureaucratic ways of thinking and begin bureaucratizing medicine themselves. An example is evidence-based medicine (EBM), which has influenced national guidelines and standards (Hasselbladh \& Bejerot 2007). EBM is a rationalization of clinical work, in which individual physicians' judgments and experiences are seen as problematic - not as a fundamental part of their work (cf. Armstrong 2002). Another rationalization of professional practices is the use of national quality registers, also run by physicians. These registers were founded in the 1980s and include all Swedish patients with a diagnosis for certain medical conditions. They have been used to compare clinics and identify quality indicators for national guidelines and have been extended to include data from patient surveys. Blomgren (2007) argues that the use of registers is legitimated by the increased demand for transparency and has opened up for practitioners from nonmedical professions to discuss issues like health care quality.

Consequently, the image of a fundamental conflict of interest between management (politicians and managers) and professionals (physicians, nurses, etc.) is too simplistic. Bejerot and Hasselblad (2013) argue that the multifaceted challenges to physicians' autonomy have happened gradually and cannot be reduced to increased managerial control. Audits, assessments, evaluations, political interventions through new legislation, and demands for increased professional efficiency constitute other elements.

The view of the patient has evolved from a patient with only medical needs to incorporate the notion of patient as customer (Liff \& Andersson 2011). This has led to an increased emphasis on control aimed at improving patient satisfaction (Hasselbladh $\&$ Bejerot 2007) and has created a patient image based on surveys and assessments of patient needs by managers, politicians, and physicians. Controlling waiting and treatment times have generally improved access to both primary health care and hospitals; yet, the effects on medical quality are debatable (Andersson 2013). 
In the Swedish school system, the general development has been described as a process of de-professionalization. Reforms have replaced autonomy with management (Ringarp 2011; Stenlås 2009), and other occupational groups, such as principals, economic controllers, and administrators have strengthened their positions (Ekholm et al. 2000; Ringarp 2011). In Sweden's highly market-oriented system (Schriber 2015), this is even more notable in private schools. Management has become integral and appears in many guises, whereas pedagogy has become more uniform, contrary to the intentions of reformers, who sought to increase pedagogical diversity (Parding \& Berg-Jansson 2016). The lack of pedagogical knowledge among principal governing bodies partially accounts for this increased interest in managerial control forms, in concord with the demise of collegial forms of coordination and control. Therefore, teachers' work is increasingly controlled and managed by an employer with a lack of knowledge in pedagogy and sensibility toward the reality of everyday teacher work (Ringarp 2011).

Skoog (2015) shows how increased demand for management, particularly by quantitative measures, has required principals to translate everyday pedagogical work into financialized performance measures. Conflicts are inherent when standardized quantitative measures meet goals oriented toward cooperation and communication (Kristiansson 2006), and formal criteria in performance appraisals must be contextualized and interpreted by school managers (Neu Morén 2015). As Bolander and Asplund (2015) demonstrate, the more objective are the criteria for teacher promotion, the more difficult they are to contextualize, rendering the role of the school leader paramount: School managers have to communicate criteria and negotiate with teachers regarding their application (Brüde Sundin 2007, Ludvigsson 2009; Tillberg 2003).

The market orientation of the Swedish schools system affects teachers' work. Teachers in private schools experience high demands for flexibility and greater short-term orientation. Their work has also expanded to include marketing activities, but the impact, if any, on the classroom remains unexplored (Lundström \& Parding 2011). Fredriksson (2010) argues that market orientation has an impact through increased bureaucratization, as demands for control and accountability have increased. Such control systems are abstract and lack detail, however, and often require interpretation, allowing space for teacher autonomy.

Teachers' work (apart from classroom work) is highly fragmented and characterized by intense, repeated interaction with other teachers and school managers. Aili (2007) and Aili and Brante (2007) illustrate this fragmentation and the ad hoc nature of teachers' work; they must manage several issues simultaneously, and risk leaving some issues unattended. Moreover, time for reflection and pedagogical development is scarce, and teachers have little autonomy in their everyday work outside the classroom. New tasks have been added to their workload (Knutas 2008).

\section{Trend 2: Increasing professional stratification}

Physicians can be appointed as managers in order to integrate professional and managerial control. But Swedish examples mirror international examples, showing that although physicians assume limited organizational responsibilities and tend not to see themselves as managers, they become more powerful physicians in their combined role (Andersson 2015; Cregård \& Eriksson 2015; Öfverström 2008). Nurses who become health care 
managers change more than physicians do; their managerial role becomes a career step (Berg \& Byrkjeflot 2014), and they substantially integrate their professional and organizational roles (Blomgren 1999, 2003). This role redesign can change the relationships between professions; nurse-managers can challenge physicians - a situation that would be nearly impossible based solely on their professional roles (Berg \& Byrkjeflot 2014).

As management models are added cumulatively multifaceted, complex management is created, with many control interfaces (Andersson \& Liff 2012). The change was initially from pre-NPM, professionally oriented control toward increased managerialism. The past decade has been characterized by cooperative and hybrid management forms in which both forms of control have been integrated - through multiprofessional teams with a manager as a team leader, for example - leading to conflicts between professional and managerial control. When professional and organizational goals have been clearly aligned, integration has been more successful. Physicians in managerial positions increase their influence and represent a key category of actors managing change (Blomgren \& Waks 2015). Using EBM processes, senior representatives of the profession are able to reconcile professional, market, and bureaucratic logic. Hybrid professionals translate nonprofessional logics into professional logic to ensure that their professional logic remains intact and professional autonomy continues to dominate. Although EBM may decrease physician autonomy, nurses may gain autonomy by transforming themselves from carers into curers of patients (Ernst 2016). Yet, this change comes with a price, because nurses experience work intensification when expansion of their professional field happens simultaneously with increasing demands from patients as customers, based on NPM logic (Selberg 2013). According to Freidson (2001), this illustrates an increased stratification within professional groups, as some professionals end up with a distinctly different set of tasks.

School managers, primarily principals, have increased their influence over schools and teachers' work (Svensson 1998), although they are not required to be teachers themselves. They became mediators between NPM control ideals and everyday pedagogical work. Whereas normatively inclined studies emphasize the value of principals with a thorough understanding of pedagogy and teachers' work (Ekholm et al. 2000), studies of principals' everyday work situation emphasize the incompatibility of these different logics: bureaucratic control versus teachers' demands for autonomy and parents' and pupils' demands for quality (Österlind et al. 2007). Change initiatives that are contrary to teachers' ideals are often met with protests, complaints, or passive resistance (Tengblad 2015). The role of principals has become increasingly administrative and oriented toward external stakeholders, which limits the possibilities for substantial dialogue and leadership on pedagogical issues (Löwstedt 2015). This has also enabled role expansion for school leaders, increasingly incorporating various notions of leadership in addition to the pedagogical roles (Svensson 1998), and school leaders are evolving into a separate profession (i.e., through specialized university training).

Moreover, recent reforms within the Swedish teaching profession have contributed to increased stratification. In 2011, teacher certification was implemented, creating a differentiation between teachers with appropriate educational background and those lacking (Lilja 2013). Furthermore, the so-called 'first teacher reform', initiated in 2015, seeks to identify and reward elite teachers. First, teachers are appointed by principals or local school authorities, and have come to take on responsibilities for competence development, pedagogical projects, and have increased teachers' representation in school 
management. They thus have become a form of elite professionals, whose interests are aligned with principals and school managers as well as with teachers. First, teachers have increased the power of the teaching profession, as they have taken control of core professional activities such as training and have gained influence in strategic issues by working closer to top management in schools (Alvehus et al, forthcoming).

\section{Trend 3: Professionals retaining autonomy}

Although management models in health care have gradually become stronger, management still has difficulty directly influencing the professions (Andersson \& Liff 2012). Management models and professional practice tend to be loosely coupled (Eriksson 2005; Fältholm \& Jansson 2008), creating parallel practices with limited influence on professional practice (Aidemark 2001; Hallin \& Kastberg 2002; Kastberg \& Siverbo 2013). Levay and Waks (2009) explain how professionals render evaluations from other parties harmless by controlling the definitions of key evaluation criteria. National guidelines, quality-control standards, and evaluations aimed at delimiting professional autonomy mobilize an elite group of professionals who work with these evaluation criteria, while the main part of the profession remains passive or indifferent.

Even if quality control enabled other actors to challenge the autonomy of physicians (Hasselbladh \& Bejerot 2017), this change has not come easily. Although most Swedish hospitals work with quality development based on improvement science from the manufacturing industry (Bergman et al. 2015), with concepts such as lean production (Eriksson et al. 2016) and process design (Hellström et al. 2010), they are met with skepticism from the medical profession (Gadolin \& Andersson 2017). Managers' and consultants' improvement efforts generally have a difficult time gaining traction if physicians are not involved. Therefore, physicians gain a veto position in relation to these processes, so their position, status, and autonomy is seldom threatened by quality-improvement efforts originating outside the profession.

The medical profession has efficiently adapted to new circumstances and mobilized its professional logic in various ways. There are differences, however, in professionals' resistance to control attempts. Psychiatry is more exposed than somatic health care is, for instance (Andersson \& Liff 2012; Arman et al. 2014; Kamp \& Dybbroe 2016). Moreover, relationships between gender and professions are highly complex and female physicians may have greater exposure to managerial interventions because they experience less support from their work group (Falkenberg et al. 2015). The strength of the professional position influences the ability of managerial logic to intervene in professional logics.

The role of school managers has become increasingly significant in Swedish schools, but mainly in their administrative role. As the role has shifted toward the administrative, their influence over everyday work processes has decreased (Löwstedt 2015).

The Swedish teaching profession underwent homogenization during the latter half of the 20th century, with decreasing differentiation among types of teachers and the level at which they teach. Although there have been recent reforms intended to lessen homogeneity, the profession is still reluctant to acknowledge teacher role differentiation (Lilja 2014). It is possible to identify generic changes within the profession, but the reception of these modifications vary by locale (Brüde Sundin 2007). Generally, whereas changes in the Swedish school context are often seen as significant, such processes are 
only loosely coupled to teachers' work, and the impact from top management is largely overrated (Larsson \& Löwstedt 2010). Although managerial intervention may influence teachers' work situation (Persson 2006), teacher autonomy is a multifaceted phenomenon (Frostenson 2015). There are strong indications that teachers still enjoy autonomy in their classrooms (von Schantz Lundgren 2008), partly because school managers have little insight in this work, complicating performance appraisal (Bolander \& Asplund 2015; Neu Morén 2015).

\section{Discussion}

Bureaucracy has to some extent taken charge of defining professionalism. Although this change has been noted previously, the reasons for and consequences of these changes have been interpreted differently. In the literature on hybrid professionalism, Kirkpatrick and Noordegraaf (2015) note that professionals actively seek the legitimacy provided by bureaucracy, whereas Evetts (2011) notes that a new organizational professionalism appropriates and transforms professional ideals in accordance with bureaucratic logic. Such trends can be seen in the attempts of health care organizations to establish standards for 'good care', by not only implementing EBM and patient-safety legislation, for example, but also through new roles that cross both organizational and professional boundaries (Currie et al. 2009). Thus, bureaucratic rules have circumvented traditional professional concerns such as ethics and responsibility, and supplanted them with standardized controls and measurement. In schools, pedagogy has become more uniform and teachers' work increasingly controlled by a principal lacking substantial pedagogical competence. Market orientation accentuates these trends and has intensified teacher work by enforcing extracurricular activities.

Increased stratification within professions is prominent. When pseudo-professions as quality developers have emerged, and nonphysician managers have come onto the scene, physicians have begun to lose their monopoly on defining quality. Moreover, the emergence of EBM has led to the development of elite professionals occupying a hybrid position, as their main task is to formalize and standardize professional norms, transforming a formerly judgment-based professional logic to formal bureaucratic logic. Recent school reforms, such as the introduction of 'first teachers', have explicitly aimed at creating stratifications within the teaching profession, by charging these elite teachers with the development of schools and pedagogic forms founded on bureaucratic legitimacy. Moreover, the role of the principal has become more prominent, as principals become gatekeepers between professional and bureaucratic logic.

Simultaneously, professionals repeatedly show a strong resilience toward changes in work practices. Whereas school reforms have been frequent, and have sometimes pushed in different directions, everyday classroom work seems largely unaffected. In health care, physicians' status has enabled them to avoid or even ignore managerial attempts at intervention. In general, whereas the trend is toward increased bureaucracy, this bureaucratic control becomes weaker the closer one gets to everyday work practices - at least partially an effect of increased stratification and division of labor within professions.

The new professional landscape emerging from these developments is one in which power relationships fluctuate, and simultaneous processes of centralization and decentralization occur. The outcomes may at first appear paradoxical. 
One outcome is that decentralisation leads to centralisation. As nurses and physicians become elite professionals, their power is amplified (cf. Currie et al. 2009), and teachers gain power by becoming first teachers. Furthermore, the power of managers in both sectors has been enhanced. To some extent, these two observations illustrate new divisions of labor and stratifications within professions. And although governmental initiatives have aimed toward decentralization, these adjustments have led to increased centralization at the local level. As Mintzberg (1979) noted nearly 40 years ago, external pressures for accountability tend to increase centralization.

A second outcome is that increased centralized control enables local autonomy. Organizations, particularly professional organizations, must be understood as loosely coupled systems (Weick 1976) in which actions at different hierarchical levels may not necessarily align. In both sectors reviewed here, everyday work is only partially affected by changes in accountability and formalization. In health care, elite professionals have taken a position where they shape evaluation criteria and control initiatives of their profession to serve their own agenda. In schools, the ambiguity of standardized forms of evaluation give rise to local adaptation, where the new first teachers have gained a prominent role. The division of labor and professional stratification that accompanies local centralization thus has the paradoxical effect of increasing local autonomy.

It is possible to conceptualize a decentralization-centralization-decentralization relationship, in which governmental decentralization initiatives give rise to local centralization. On the other hand, increased decoupling between everyday professional practice and bureaucratic controls prevents centralization. There are no clear evidence of a straight-forward subsuming of professional logic to that of the market or bureaucracy; neither do we find any clear cases of hybrid organizations, as the different logics remain in potential conflict, resolved by parallel processes of decentralization and centralization. Finally, while autonomy has to some extent been retained, there is no denying that control forms have affected work processes as different norms of evaluation have been implemented, professional stratifications are changing, and in some cases work intensification is evident. Thus, we find neither loss of professional autonomy, nor increased hybridization, nor a decoupled autonomy. Instead, we find a situation of entangled institutional logics, enabled by a simultaneous and paradoxical decentralizationcentralization-decentralization relationship.

\section{Conclusion}

The new professional landscape that emerges from this analysis is complex and paradoxical. The three views on professional development identified - loss of professional autonomy, hybridization, and maintained autonomy - all have merit, which can be partially understood as developing on different levels simultaneously (Frostenson 2015). But, drawing on recent developments in institutional theory, another explanation can be suggested. The inhabited institutions approach is based on the assumption that processes of institutionalization are always local, and whereas abstract views on institutions are valuable as theoretical constructs, they must always be understood as de facto developing in concrete empirical contexts. This is not a question of levels of analysis, therefore, but of entangled institutional logics, wherein simultaneous and paradoxical effects occur. 
The new professional landscape emerging from this analysis is one in which professionalism is not immediately threatened but coexisting with increased managerial initiatives (Kamp 2016). Professionals seem to be consistently skilled in avoiding changes in their institutional context and conducting business as usual - particularly in highstatus professions (Currie et al. 2009). Moreover, professions are undergoing a process of stratification, primarily through the creation of elite professionals who reinstate the status of the profession, thereby also changing the core knowledge base of professionalism (cf. Prowse \& Prowse 2008). In this, as Evetts (2011) suggests, there are tendencies for professionalism to become co-opted by bureaucracy, as in EBM in health care and in the first-teacher reform.

A more complete understanding of the new professional landscape must rely on closer studies of institutional processes. This professional landscape seems to include a strong trend toward hybridism, as the pressure from bureaucracy has enforced a situation in which different logics are forced to coexist. A question arises, however: Has hybridism penetrated to the level of everyday work, or is it merely superficial (Alvehus 2018)? The answer lies in the observations of the decentralization-centralization-decentralization relationship and in that hybridity is tightly yet loosely coupled. To the managerphysician, things may be tightly coupled in a management meeting, but rapidly loosen when facing a patient. A teacher may be skilled at talking about core values and quality assessment, but the impact of those factors in the classroom may be limited - although the teacher may claim otherwise. The new professional landscape consists of institutional logics that are always entangled yet simultaneously tightly and loosely coupled, a situation enabled by the decentralization-centralization-decentralization relationship.

\section{References}

Adams, T. L. (2015). Sociology of professions: international divergences and research directions, Work, Employment and Society 29(1): 154-165. doi: http://dx.doi.org/ $10.1177 / 0950017014523467$.

Adler, P. S., Kwon, S. W., \& Heckscher, C. (2008). Professional work: The emergence of collaborative community, Organization Science 19(2): 359-376. doi: http://dx.doi. org/10.1287/orsc.1070.0293.

Aidemark, L. G. (2001). The meaning of balanced scorecards in the health care organisation, Financial Accountability and Management 17(1): 23-40. doi: http://dx.doi.org/ 10.1111/1468-0408.00119.

Aili, C. (2007). Time-formatives and intermittent work. School and teacher's work in practice. In: Aili, C., Nilsson, L.-E., Svensson, L. G., \& Denicolo, P. (eds), In Tension Between Organization and Profession. Professionals in Nordic Public Service, Lund: Nordic Academic Press. pp. 193-225.

Aili, C. \& Brante, G. (2007). Qualifying teacher work: everyday work as basis for the autonomy of the teaching profession, Teachers and Teaching 13(3): 287-306. doi: http://dx.doi. org/ 10.1080/13540600701299791.

Almqvist, R. (2004). Icons of New Public Management. Four Studies on Competition, Contracts and Control, Dissertation. Stockholm: Stockholm University.

Alvehus, J. (2018). Conflicting logics? The role of HRM in a professional service firm, Human Resource Management Journal 28(1):31-44. doi: http://dx.doi.org/10.1111/1748$\underline{8583.12159 .}$. 
Alvehus, J., Eklund, S., \& Kastberg, G. (forthcoming). Stärkt, splittrad och styrd. Förstelärarreformen i kritisk belysning. [Strengthened, Stratified, and Controlled. A Critical View on the First Teacher Reform], Lund: Studenlitteratur.

Alvehus, J., \& Spicer, A. (2012). Financialization as a strategy of workplace control in professional service firms, Critical Perspectives on Accounting 23(7-8): 497-510. http://dx.doi. org/doi:10.1016/i.cpa.2012.02.001.

Andersson, T. (2013). Förutsättningar för förbättringsarbete i vården [Conditions for improvement work in health care]. In: Eriksson, N., Holgers. K. M., \& Müllern, T. (eds) Att utveckla vården - Om erfarenheter av kvalitet, verksamhetsutveckling och förbättringsarbete [Developing Health Care - On Experiences of Quality, Development, and Improvement Work], Lund: Studentlitteratur. pp. 121-142.

Andersson, T. (2015). The medical leadership challenge in healthcare is an identity challenge, Leadership in Health Services 28(2): 83-99. doi: http://dx.doi.org/10.1108/LHS04-2014-0032.

Andersson, T., \& Liff, R. (2012). Multi-professional cooperation and accountability pressures - Consequences of a post-new public management reform in a new public management context, Public Management Review 14(6): 835-855. doi: http://dx.doi.org/10.108 0/14719037.2011.650053.

Andersson, T., \& Liff, R. (2018). Co-optation as a response to competing institutional logics: professionals and managers in healthcare, Journal of Professions and Organization 5(2): 71-87. doi: http://dx.doi.org/10.1093/jpo/joy001.

Andersson, T., \& Tengblad, S. (2009). When complexity meets culture: New Public Management and the Swedish police, Qualitative Research in Accounting and Management 6(1/2): 41-56. doi: http://dx.doi.org/10.1108/11766090910940656.

Arman, R., Liff, R., \& Wikström, E. (2014). The hierarchization of competing logics in psychiatric care in Sweden, Scandinavian Journal of Management 30(3): 282-291. doi: http://dx.doi.org/10.1016/j.scaman.2014.01.001.

Armstrong, D. (2002). Clinical autonomy, individual and collective: the problem of changing doctors' behaviour, Social Science och Medicine 55(10): 1771-1777. doi: http://dx.doi. org/10.1016/S0277-9536(01)00309-4.

Battilana, J., \& Dorado, S. (2010). Building sustainable hybrid organizations: the case of commercial microfinance organizations, Academy of Management Journal 53(6): 14191440. doi: http://dx.doi.org/10.5465/AMJ.2010.57318391.

Bejerot, E., \& Hasselbladh, H. (2013). Forms of intervention in public sector organizations: generic traits in public sector reforms, Organization Studies 34(9): 1357-1380. doi: http://dx.doi.org/10.1177/0170840613477639.

Belfrage, C. (2008). Towards 'universal financialisation' in Sweden? Contemporary Politics 14(3): 277-296. doi: http://dx.doi.org/10.1080/13569770802396337.

Berg, L. N., \& Byrkjeflot, H. (2014). Management in hospitals: a career track and a career trap. A comparison of physicians and nurses in Norway, International Journal of Public Sector Management 27(5): 379-394. doi: http://dx.doi.org/10.1108/IJPSM-11-2012-0160.

Bergman, B., Hellström, A., Lifvergren, S., \& Gustavsson, S. (2015). An emerging science of improvement in health care, Quality Engineering 27(1): 17-34. doi: http://dx.doi.org/10.10 80/08982112.2015.968042.

Bévort, F., \& Suddaby, R. (2016). Scripting professional identities: how individuals make sense of contradictory institutional logics, Journal of Professions and Organization 3(1): 17-38. doi: http://dx.doi.org/10.1093/jpo/jov007.

Blomgren, M. (1999). Pengarna eller livet: Sjukvårdande professioner och yrkesgrupper i mötet med ny ekonomistyrning [Your Money or Your Life: Caring Professions and Occupations in the Meeting of New Management Control]. Dissertation, Uppsala: Uppsala University. 
Blomgren, M. (2003). Ordering a profession: Swedish nurses encounter new public management reforms, Financial Accountability och Management 19(1): 45-71. doi: http:// dx.doi.org/ 10.1111/1468-0408.00163.

Blomgren, M. (2007). The drive for transparency: organizational field transformations in Swedish healthcare, Public Administration 85(1): 67-82. doi: http://dx.doi.org/10.1111/ j.1467-9299.2007.00634.x.

Blomgren, M., \& Waks, C. (2015). Coping with contradictions: hybrid professionals managing institutional complexity, Journal of Professions and Organization 2(1): 78-102. doi: http://dx.doi.org/ 10.1093/jpo/jou010.

Bolander, P., \& Asplund, K. (2015). Talent management i skolan - utvärdering och utveckling i förändring. [Talent management in schools - changing assessment and development] In: Löwstedt, J. (ed.) Skolledning. Scener från den organiserade vardagen [School management. Scenes from everyday organizing], Lund: Studentlitteratur: 59-77.

Brüde Sundin, J. (2007). En riktig rektor. Om ledarskap, genus och skolkulturer [A Real Principal. On Leadership, Gender and School Cultures]. Dissertation, Linköping: Linköping University.

Brunsson, N. (1989). The Organization of Hypocrisy. Talk, Decisions, and Actions in Organizations, Chichester: Wiley.

Collin, K., Paloniemi, S., \& Vähäsantanen, K. (2015). Multiple forms of professional agency for (non)crafting of work practices in a hospital organization, Nordic Journal of Working Life Studies 5(3a): 63-83. doi: http://dx.doi.org/10.19154/njwls.v5i3a.4834.

Cooper, D. J., Hinings, B., Greenwood, R., \& Brown, J. (1996). Sedimentation and transformation in organizational change: the case of Canadian law firms, Organization Studies 17(4): 623-647. doi: http://dx.doi.org/10.1177/017084069601700404.

Covaleski, M. A., Dirsmith, M. W., Heian, J. B., \& Samuel, S. (1998). The calculated and the avowed: techniques of discipline and struggles over identity in Big Six public accounting firms, Administrative Science Quarterly 43: 293-327. doi: http://dx.doi. org/10.2307/2393854.

Cregård, A., \& Eriksson, N. (2015). Perceptions of trust in physician-managers, Leadership in Health Services 28(4): 281-297. doi: http://dx.doi.org/10.1108/LHS-11-2014-0074

Currie, G., Finn, R., \& Martin, G. (2009). Professional competition and modernizing the clinical workforce in the NHS, Work, Employment and Society 23(2): 267-284. doi: http:// dx.doi.org/10.1177/0950017009102858.

Dan, S., \& Pollitt, C. (2015). NPM can work: an optimistic review of the impact of New Public Management reforms in central and eastern Europe, Public Management Review 17(9): 1305-1332. doi: http://dx.doi.org/10.1080/14719037.2014.908662.

DiMaggio, P. J., \& Powell, W. J. (1983). The iron cage revisited: Institutional isomorphism and collective rationality in organizational fields, American Sociological Review 48(2): 147-160. doi: http://dx.doi.org/10.2307/2095101.

Dirsmith, M. W., Heian, J. B., \& Covaleski, M. A. (1997). Structure and agency in an institutionalized setting: the application and social transformation of control in the Big Six, Accounting, Organizations and Society 22(1): 1-27. doi: http://dx.doi.org/10.1016/ S0361-3682(96)00005-0.

Ekholm, M., Blossing, U., Kåräng, G., Lindvall, K., \& Scherp, H.-Å. (2000). Forskning om rektor - en forskningsöversikt [Research About the Principal - a Research Overview], Stockholm: Liber.

Eriksson, A., Holden, R., Williamsson, A., \& Dellve, L. (2016). A case study of three Swedish hospitals' strategies for implementing lean production, Nordic Journal of Working Life Studies 6(1): 105-131. doi: http://dx.doi.org/10.19154/njwls.v6i1.4912.

Eriksson, N. (2005). Friska vindar i sjukvården - Stöd och hinder vid förändringar i professionella organisationer [Healthy Winds in Health Care - Support and Obstacles 
in Changing Professional Organizations]. Dissertation, Gothenburg: Gothenburg University.

Ernst, J. (2016). Evidence-based nursing in IED: From caring to curing? Nordic Journal of Working Life Studies 6(S1): 47-66. doi: http://dx.doi.org/10.19154/njwls.v6i1.4885

Everitt, J. G. (2012). Teacher careers and inhabited institutions: sense-making and arsenals of teaching practice in educational institutions, Symbolic Interaction 35(2): 203-220. doi: http://dx.doi.org/10.1002/symb.16.

Everitt, J. G. (2013). Inhabitants moving in: prospective sense-making and the reproduction of inhabited institutions in teacher education, Symbolic Interaction 36(2): 177-196. doi: http://dx.doi.org/10.1002/symb.56.

Evetts, J. (2011). A new professionalism? Challenges and opportunities, Current Sociology 59(4): 406-422. doi: http://dx.doi.org/10.1177/0011392111402585.

Falkenberg, H., Näswall, K., Lindfors, P., \& Sverke, M. (2015). Working in the same sector, in the same organization and in the same occupation: similarities and differences between women and men physicians' work climate and health complaints, Nordic Journal of Working Life Studies 5(4): 67-84. doi: http://dx.doi.org/10.19154/njwls.v5i4.4844.

Fältholm, Y., \& Jansson, A. (2008). The implementation of process orientation at a Swedish hospital, International Journal of Health Planning and Management 23(3): 219-233. doi: http://dx.doi.org/10.1002/hpm.884.

Faulconbridge, J. R., \& Muzio, D. (2008). Organizational professionalism in globalizing law firms, Work, Employment and Society 22(1): 7-25. doi: http://dx.doi.org/10. $1177 / 0950017007087413$.

Fredriksson, A. (2010). Marknaden och lärarna. Hur organiseringen av skolan påverkar lärares offentliga tjänstemannaskap [The Market and the Teachers. How School Organizing Affects Teachers as Office Bearers]. Dissertation, Göteborg: Göteborg University.

Freidson, E. (2001). Professionalism. The Third Logic, Chicago: The University of Chicago Press.

Frostenson, M. (2015). Three forms of professional autonomy: de-professionalisation of teachers in a new light, Nordic Journal of Studies in Educational Policy 2015(2): 28464. doi: http://dx.doi.org/10.3402/nstep.v1.28464.

Gadolin, C., \& Andersson, T. (2017). Healthcare quality improvement work: a professional employee perspective, International Journal of Health Care Quality Assurance 30(5): 410-423. doi: http://dx.doi.org/10.1108/IJHCQA-02-2016-0013.

Goodrick, E., \& Reay, T. (2011). Constellations of institutional logics: changes in the professional work of pharmacists, Work and Occupations 38(3): 372-416. doi: http://dx.doi. org/10.1177/0730888411406824.

Greenwood, R., Hinings, C. R., \& Brown, J. (1990). 'P2-form' strategic management: Corporate practices in professional partnerships, The Academy of Management Journal 33(4): $725-755$.

Hallett, T. (2010). The myth incarnate: recoupling processes, turmoil, and inhabited institutions in an urban elementary school, American Sociological Review 75(1): 52-74. doi: http://dx.doi.org/10.1177/0003122409357044.

Hallett, T., \& Ventresca, M. J. (2006). Inhabited institutions: social interactions and organizational forms in Gouldner's patterns of industrial bureaucracy, Theory and Society 35(2): 213-236. doi: http://dx.doi.org/10.1007/s11186-006-9003-z.

Hallin, B., \& Kastberg, G. (2002). Balanced scorecard i teori och praktik: en flerdimensionell styrmodell i hälso- och sjukvården [Balanced Scorecard in Theory and Practice: A Multidimensional Control Model in Health Care], Gothenburg: Gothenburg University.

Hasselbladh, H., \& Bejerot, E. (2007). Webs of knowledge and circuits of communication: constructing rationalized agency in Swedish health care, Organization 14(2): 175-200. doi: http://dx.doi.org/10.1177/1350508407074223. 
Hasselbladh, H., \& Bejerot, E. (2017). Performative policy: the case of Swedish health care reforms, Critical Policy Studies 11(3): 291-310. doi: http://dx.doi.org/10.1080/1946017 1.2016.1166973.

Hasselbladh, H., Bejerot, E., \& Gustafsson, R. Å. (2008). Bortom New Public Management Institutionell transformation i svensk sjukvård [Beyond New Public Management Institutional Transformation in Swedish health care], Lund: Academia Adacta.

Hellström, A., Lifvergren, S., \& Quist, J. (2010). Process management in healthcare - investigating why it's easier said than done, Journal of Manufacturing Technology Management 21(4): 499-511. doi: http://dx.doi.org/10.1108/17410381011046607.

Hood, C. (1995). The 'New Public Management' in the 1980s: variations on a theme, Accounting, Organizations and Society 20(3): 93-109. doi: http://dx.doi.org/10. 1016/0361-3682(93)E0001-W.

Hood, C., \& Dixon, R. (2015). A Government That Worked Better and Cost Less? Oxford: Oxford University Press.

Kamp, A. (2016). Welfare professions in transition, Nordic Journal of Working Life Studies 6(S1): 1-6. doi: http://dx.doi.org/10.19154/njwls.v6i1.4882.

Kamp, A., \& Dybbroe, B. (2016). Struggles of professionalism and emotional labour in standardized mental health care, Nordic Journal of Working Life Studies 6(S1): 67-86. doi: http://dx.doi.org/10.19154/njwls.v6i1.4886.

Kamp, A., Klemsdal, L., \& Gonäs, L. (2013). Working in the public sector. Introduction to the thematic issue, Nordic Journal of Working Life Studies 3(2): 1-8. doi: http://dx.doi. org/10.19154/njwls.v3i2.2547.

Karlsson, T. S. (2017). Shaping NPM: social democratic values at work. In: Lapsley, I., \& Knutsson, H. (eds.) Modernizing the Public Sector: Scandinavian Perspectives, London: Routledge. pp. 37-52.

Kastberg, G., \& Siverbo, S. (2013). The design and use of management accounting systems in process oriented health care - an explorative study, Financial Accountability och Management 29(3): 246-270. doi: http://dx.doi.org/10.1111/faam.12014.

Kirkpatrick, I., \& Noordegraaf, M. (2015). Organizations and occupations: towards hybrid professionalism in professional service firms? In: Empson, L., Hinings, R., Muzio, D., \& Broschak, J. (eds) Oxford Handbook of Professional Service Firms, Oxford: Oxford University Press. pp. 92-112.

Knutas, A. (2008). Mellan styrning och moral. Berättelser om ett lärarlag [Between Control and Morality: Narratives About a Teaching Team]. Dissertation, Örebro: Örebro University.

Kristiansson, M. (2006). Skolan och den politiska offentligheten - öppning eller tillslutning? Styrning och skolutveckling utifrån 'försöket utan timplan' [The School and the Political Public - Opening or Closure? Control and School Development in 'the No-schedule Experiment']. Dissertation, Karlstad: Karlstad University.

Larsson, P., \& Löwstedt, J. (2010). Strategier och förändringsmyter - ett organisationsperspektiv på skolutveckling och lärares arbete [Strategies and Myths of Change - an Organizational Perspective on School Development and Teacher Work], Lund: Studentlitteratur.

Levay, L., \& Waks, C. (2009). Professions and the pursuit of transparency in health care: two cases of soft autonomy, Organization Studies 30(5): 509-527. doi: http://dx.doi. org/10.1177/0170840609104396.

Liff, R., \& Andersson, T. (2011). Integrating or disintegrating effects of customised care the role of professions beyond NPM, Journal of Health Organization and Management 25(6): 658-676. doi: http://dx.doi.org/10.1108/14777261111178547.

Lilja, P. (2013). A quest for legitimacy: on the professionalization policies of Sweden's teachers' unions, Journal of Education Policy 29(1), 86-104. 
Lilja, P. (2014). Negotiating Teacher Professionalism. On the Symbolic Politics of Sweden's Teacher Unions. Dissertation, Malmö: Malmö University.

Löwstedt, J. (2015). Skolledning i organisationssamhället [School management in organizational society]. In: Löwstedt, J. (ed.) Skolledning. Scener från den organiserade vardagen [School Management. Scenes from Everyday Organizing], Lund: Studentlitteratur.

Ludvigsson, A. (2009). Samproducerat ledarskap. Hur rektorer och lärare formar ledarskap i skolans vardagsarbete [Co-produced Leadership. How Principals and Teachers Shapa Leadertship in Everyday School Work]. Dissertation, Jönköping: Jönköping University.

Lundström, U., \& Parding, K. (2011). Lärares upplevelser av friskolereformen - effekter av marknadiseringen av den svenska gymnasieskolan [Teachers' Experience of School Deregulation - Consequences of the Marketization of the Swedish High School], Arbetsmarknad och Arbetsliv 17(4): 59-77.

Meyer, J. W., \& Rowan, B. (1977). Institutionalized organizations: formal structure as myth and ceremony, American Journal of Sociology 83(2): 340-363. doi: http://dx.doi.org/10. $1086 / 226550$.

Mintzberg, H. (1979). The Structuring of Organizations: A Synthesis of the Research, Englewood Cliffs: Prentice-Hall.

Molander, P. (2017). Dags för omprövning [Time for Reconsideration]. Rapport till Expertgruppen för studier i offentlig ekonomi 2017:1, Stockholm: Regeringskansliet, Finansdepartementet.

Montin, S. (1997). New Public Management på svenska [New public management in Swedish], Politica 29(3): 262-278.

Neu Morén, E. (2015). Att bedöma arbetsprestationer och sätta lön [Assessing work performance and wage-setting]. In: Löwstedt, J. (ed.) Skolledning. Scener från den organiserade vardagen [School Management. Scenes from Everyday Organizing], Lund: Studentlitteratur: $79-94$.

Öfverström, H. (2008). Steget till chefskap. Om läkare som verksamhetschefer [The Step to Management. On Physicians as Managers]. Dissertation, Göteborg: Göteborg University.

Österlind, M.-L., Denicolo, P., \& Johansson, C.-R. (2007). Head teachers caught in the middle or top of things? In: Aili, C., Nilsson, L.-E., Svensson, L. G., \& Denicolo, P. (eds) In Tension Between Organization and Profession. Professionals in Nordic Public Service, Lund: Nordic Academic Press. pp. 133-153.

Pache, A. C., \& Santos, F. (2013). Inside the hybrid organization: selective coupling as a response to competing institutional logics, Academy of Management Journal 56(4): 9721001. doi: http://dx.doi.org/10.5465/amj.2011.0405.

Parding, K. Å., \& Berg-Jansson, A. (2016). Teachers' working conditions amid Swedish school choice reform: avenues for further research, Professions and Professionalism 6(1): 1-16. doi: http://dx.doi.org/10.7577/pp.1416.

Persson, A. (2006). Nöjda som lärare, missnöjda som anställda [Satisfied as teachers, dissatisfied as employees]. In: Petersson, H., Leppänen, V., Jönsson, S., \& Tranquist, J. (eds.) Villkor i arbete med människor - en antologi om human servicearbete [Conditions for Working with People - an Anthology About Human Service Work], Katrineholm: Arbetslivsinstitutet.

Prowse, J., \& Prowse, P. (2008). Role redesign in the National Health Service: the effects on midwives' work and professional boundaries, Work, Employment and Society 22(4): 695-712. doi: http://dx.doi.org/10.1177/0950017008096743.

Reay, T., \& Hinings, C. R. (2009). Managing the rivalry of competing institutional logics, Organization Studies 30(6): 629-652. doi: http://dx.doi.org/10.1177/0170840609104803.

Ringarp, J. (2011). Professionens problematik. Lärarkårens kommunalisering och välfärdsstatens förvandling [The Problems of the Profession. The Municipalization of Swedish Teachers and the Transformations of the Welfare State], Dissertation. Göteborg: Makadam. 
Scott, W. R. (2008). Lords of the dance: professionals as institutional agents, Organization Studies 29(2): 219-238. doi: http://dx.doi.org/10.1177/0170840607088151.

Selberg, R. (2013). Nursing in times of neoliberal change: an ethnographic study of nurses' experiences of work intensification, Nordic Journal of Working Life Studies 3(2): 9-35. doi: http://dx.doi.org/10.19154/njwls.v3i2.2548.

Schriber, S. (2015). Ledning av skolor på ofullständiga marknader [School management on imperfect markets]. In: Löwstedt J (ed.) Skolledning. Scener från den organisatoriska vardagen [School Management. Scenes from Everyday Organizing], Lund: Studentlitteratur: 171-184.

Siebert, S., Bushfield, S., Martin, G., \& Howieson, B. (2018). Eroding 'respectability': deprofessionalization through organizational spaces, Work, Employment and Society 32(2): 330-347. doi: http://dx.doi.org/10.1177/0950017017726948.

Singh, J., \& Jayanti, R. K. (2013). When institutional work backfires: Organizational control of professional work in the pharmaceutical industry, Journal of Management Studies 50(5): 900-929. doi: http://dx.doi.org/10.1111/joms.12022.

Skoog, M. (2015). Styrutmaningar i skolans mål och resultatuppföljning [Management challenges in goals and outcomes in schools]. In: Löwstedt J (ed.) Skolledning. Scener från den organisatoriska vardagen [School Management. Scenes from Everyday Organizing], Lund: Studentlitteratur. pp. 185-199.

Smets, M., Jarzabkowski, P., Burke, G. T., \& Spee, P. (2015). Reinsurance trading in Lloyd's of London: Balancing conflicting-yet-complementary logics in practice, Academy of Management Journal 58(3): 932-970. doi: http://dx.doi.org/10.5465/amj.2012.0638.

Stenlås, N. (2009). En kår i kläm - Läraryrket mellan professionella ideal och statliga reformideologier [An Occupation in Trouble - Teachers Between Professional Ideals and Governmental Control Reform Ideologies], Stockholm: Expert Group on Public Economics.

Svallfors, S., \& Tyllström, A. (2018). Resilient privatization: the puzzling case of for-profit welfare providers in Sweden, Socio-Economic Review 00(0): 1-21. doi: http://dx.doi. org/10.1093/ser/mwy005.

Svensson, L. G. (1998). Professionalism och politisk decentralisering. En sociologisk studie av skolan och socialtjänsten i en kommundelsreform [Professionalism and Political Decentralization. A Sociological Study of School and Social Work in a Municipality Reform]. Research report, Göteborg: Göteborg University.

Swart, J., Hansen, N. K., \& Kinnie, N. (2015). Strategic human resource management and performance in professional service firms. In: Empson, L., Hinings, R., Muzio, D., \& Broschak, J. (eds) Oxford Handbook of Professional Service Firms, Oxford: Oxford University Press. pp. 476-502.

Tengblad, S. (2015). Ledarskap och medarbetarskap [Leadership and co-workership]. In: Löwstedt, J (ed.) Skolledning. Scener från den organiserade vardagen [School Management. Scenes from Everyday Organizing], Lund: Studentlitteratur. pp. 109-127.

Thornton, P. H., \& Ocasio, W. (1999). Institutional logics and the historical contingency of power in organizations: executive succession in the higher education publishing industry, 1958-1990, American Journal of Sociology 105(3): 801-843. doi: http://dx.doi. org/10.1086/210361.

Tillberg, U. (2003). Ledarskap och samarbete. En jämförande fallstudie i tre skolor [Leadership and Cooperation. A Comparative Case Study in Three Schools]. Dissertation, Stockholm: Stockholm School of Economics.

von Schantz Lundgren, I. (2008). Det är enklare i teorin ... Om skolutveckling i praktiken. En fallstudie av ett skolutvecklingsprojekt i en gymnasieskola [It's Easier in Theory ... On School Development in Practice. A Case Study of a Development Project in a High School]. Dissertation, Växjö: Växjö University Press. 
Waldorff, S. B., Reay, T., \& Goodrick, E. (2013). A tale of two countries: how different constellations of logics impact action. In: Lounsbury, M., \& Boxenbaum, E. (eds) Institutional Logics in Action, Part A. Emerald: 99-129.

Wallace, J. E. (1995). Organizational and professional commitment in professional and nonprofessional organizations, Administrative Science Quarterly 40: 228-255. doi: http:// dx.doi.org/10.2307/2393637.

Weick, K. E. (1976). Educational organizations as loosely coupled systems, Administrative Science Quarterly 21(1): 1-19. doi: http://dx.doi.org/10.2307/2391875. 